CURRENT RESEARCH

\title{
RECENT SEDIMENT STUDIES
}

Sedimentation Studies in the Bay of Fundy

A series of inter-related studies in Quaternary sedimentation in the Bay of Fundy have been started by DR. D.J.P. SWIFT and students at the Institute of Oceanography, DALHOUSIE UNIVERSITY, and co-operating scientists from other institutions. Presently active projects include:

1. Tide-maintained sand bodies in the eastern Bay of Fundy, by D. SWIFT and A. LYALL (Ph.D. candidate).

2. Raised glacio-marine deposits, north shore of Minas Basin, by, H. BORNS (UNIVERSITY OF MAINE) and D. SWIFT.

3. Periglacial eolian deposits at the Debert archaeological site, north shore of Minas Basin, by D. SWIFT, D. BYERS (PEABODY FOUNDATION FOR ARCHAEOLOGY, Andover, Mass.) and D. KRINSLEY (QUEENS COLLEGE, N.Y.). A preliminary report appeared in the last issue of MARITIME SEDIMENTS (v. 2, no. 1, p. 25-30).

4. Suspended sediment transport in the Bay of Fundy, by J. MILLER (M.Sc. candidate).

Field work this spring has consisted of a two-week cruise on the Bedford Institute's corvette CNAV Sackville. Over 200 miles of subbottom sparker profiles were obtained with the Huntec Mark 2A Hydrosonde, in the Bay of Fundy, including Minas Basin and Chignecto Bay. Grab samples, piston and box cores and bottom photographs were taken in areas of interest in eastern Fundy. Particular attention was paid to the estuarine deposits of Chignecto Bay and to the sub-aqueous dune fields in the Minas Channel.

Plans are being formulated to study intertidal and subtidal sand bodies in the Minas Channel during a portion of the coming summer.

A number of publications are in press.

Marine Sediment Studies on: Bermuda Pedestal; Submarine Canyons near Sable Island; Western Scotian Shelf

Members of the Marine Geology Group, Institute of Oceanography, DALHOUSIE UNIVERSITY are participating in a series of cruises during the months of March and April, 1966 on the CNAV Sackville. The cruise, under the general supervision of DR. DANIEL J. STANLEY, has been subdivided into several phases.

During the first leg of the cruise, Recent and Pleistocene sediment distribution of the Bay of Fundy and Minas Basin area are being investigated by D.J.P SWIFT and graduate students (see previous account). During the following two-week period, scientists are investigating the morphology on selected sites of the North West Atlantic floor in the area between Halifax and Bermuda. Particular attention is being paid to part of the Kelvin Seamount chain located at approximately $39^{\circ} \mathrm{N}$ and $64^{\circ} \mathrm{W}$. Continuous recorded echograms, cores, and photographs of the 
bottom are being obtained. The sediment distribution and morphology of the Bermuda Pedestal and Apron are also under investigation.

On Bermuda the scientific party are using facilities of the BERMUDA MARINE BIOLOGICAL STATION for research. While on the island Dr. Stanley wi.11 collect oriented, undisturbed box cores in order to study primary sedimentary structures in carbonates; several environments, including the reef, will be sampled. SCUBA and photographic equipment are being used by the divers: H. BEALS, G. MANKLALOU, F. MEDIOLI, D.J. STANLEY and D.J.P. SWIFT. T.E. PICKETT of the SMITHSONIAN OCEANOGRAPHIC SORTING CENTRE and $\mathrm{J}$. WAY, Jr. are also participating in this study. Dalhousie's large Reineck-type box-corer with self-locking compass will also be used on the Bermuda Platform and upper Pedestal.

In the latter half of April, the cruise is to be devoted to an investigation of the sediment dispersal patterns in some submarine canyons in the vicinity of Sable Island. The Recent sediment fill in the Gully, the largest of the canyons which actually extends onto the Scotian Shelf east of Sable Island, will receive most emphasis. Freefalling coring devices are being used for precise sampling in the axes and walls of the canyon. Bottom photographs, PDR records, sub-bottom seismic profiles, and samples of the water column in the canyon will supplement materials for this investigation. The large box-corer will be used for obtaining oriented samples in the canyon.

Sub-bottom profiles will also be made in the Sable Island area, and temperature, salinity and bottom current data collected in order to complement the study of sediment dispersal (present1y under study by NOEL JAMES) and microfaunal distribution (Franco Medioli) on this part of the bank.

The final leg of the cruise is reserved for the completion of a detailed survey of the western half of the Scotian Shelf initiated in 1965 by GEORGES DRAPEAU and other members of the Marine Geology Group. Major emphasis will be sub-bottom profiling and interpretation of the extremely irregular topography comprising deep basins, cuesta-like highs, and broad shallow outer banks. F. Medioli will collect microfauna in tow nets in an attempt to compare the foraminifera of the water column with those in the underlying bottom shelf sediments. The survey will extend to the area of Browns Bank and the Northeast Channe1. Seismic records, bottom photographs and cores should provide the necessary material for providing the three-dimensional picture and for interpreting the Recent sediment history on the western half of the Scotian Shelf.

Microfauna and Relation to Sediments: Scotian Shelf and Slope

FRANCO MEDIOLI, who one year ago joined the Marine Geology Group of the Institute of Oceanography, DALHOUSIE UNIVERSITY, is presently working on microfaunal and ecological problems of the Scotian Shelf and slope. He is presently conducting a detailed statistical ecologica1 study of 114 samples collected on Sable Island Bank during the May 1965 I.O.Dal cruise. Examination of generic and species distributions of foraminifera is illustrating the close interdependence between fauna and both bottom morphology and sediment distribution. Data pertaining 
to chemical and physical parameters in this area are, as yet, insufficient; as a result one of the projects of the forthcoming April 1966 I.0. Dal cruise is to obtain salinity, temperature and current velocity data on the bank in the vicinity of Sable Island (see previous account).

Another major aspect under consideration is the study of living planktonic foraminifera in the water column off the continental shelf and slope off Nova Scotia. The influence of the Gulf Stream on planktonic distribution along the slope is being evaluated, as well as a comparison of the fauna in the water column and in the underlying bottom sediments.

Several studies of a more specific nature are being coordinated with sedimentologists of Dalhousie's Marine Geology Group. A statistical study of the foraminiferal fauna in the Northwest Arm near Halifax, N.S. is near completion. This is part of the bottom study of a "false-fjord" being conducted by DANIEL J. STANLEY and students. An analysis of the fauna in the large submarine canyon, the Gully, off Sable Island has also been initiated. The purpose of that study is to examine paleotemperature variations and the Pleistocene-Holocene boundary in cores collected in the sediment cover beyond the shelf-break. Problems of sediment and faunal reworking in submarine canyons and slope is being considered in conjunction with the sediment dispersal patterns in canyons project of D.J. Stanley.

A project is also underway to construct equipment for the "cultivation" of benthonic foraminifera in the laboratory. This is to begin this coming fall, with the possible collaboration of Dalhousie's Department of Biology. A statistical program for the various ecological studies is being prepared for Dalhousie's IBM 1620 computer, and Medioli would like to contact anyone working on the application of computers to problems of foraminiferal ecology.

Marine Geological Research at Bedford Institute of Oceanography

Research by members of the BEDFORD INSTITUTE OF OCEANOGRAPHY is going on in many parts of the Atlantic Region and areas to the north. On the Scotian Shelf, L.H. KING is completing a sediment distribution map based on the interpretation of echograms and bottom sampling; he is also tracing submarine benches from the sounding rolls. In the laboratory his work on the separation of organic constituents from the sediments is meeting with progressively greater success. A newly appointed sedimentologist, DR. R.M. McMULLEN, is engaged on a petrological examination of sediments from the Grand Banks of Newfoundland; MISS K.M. KRANCK is completing petrological studies on the sediments and bedrock of Northumberland Strait. She will be continuing this work for a time this summer, and is also preparing for a co-operative project in Belle Isle Strait with the Marine Sciences Centre, McGILL UNIVERSITY. The paleontologists are busy too: G.A. BARTLETT is continuing ecological study of foraminifera in the Atlantic Provinces waters, relating the results more directly to inferences concerning paleogeography and paleoclimatology. G. VILKS is continuing with correlation and association analysis work on the foraminifera of the Bras d'or Lakes, Cape Breton Island; and the fossils of the ancient Champlain Sea form the subject of an excellent manuscript recently submitted by F.J.E. WAGNER in Ottawa. 
In northern and Arctic regions, J.I. MARLOWE is completing research on mineralogical aspects of Baffin Bay sediments and their relationship to ancient currents; B.R. PELLETIER is working on bottom material from the Polar Continental Shelf and Hudson Bay; interpretation of sub-bottom profiling from the latter is being completed by A.C. GRANT, who is also preparing a note on a short cross-section off Nain, Labrador. Dr. McMullen is also preparing for a marine geological program, in Hecla and Griper Bays on Queen Elizabeth Island, District of Franklin.

University Research on the Sediments of the Atlantic Coast and Continental She1f.

Current research activity in this field by a number of institutions from Florida to the Maritime Provinces is outlined in the report of a conference held at the NATIONAL ACADEMY OF SCIENCES, Washington, D.C., on 23rd February 1966, which appears on pages $109-112$ of this issue.

\section{ANCIENT SEDIMENTS}

Al1 material in this section is collected together in the RESEARCH COMPILATION: ANCIENT SEDIMENTS on pages 88 - 99 in this issue.

\section{GEOPHYSICS}

Seismic Profiling of New England Continental Margin

A new seismic profiling system using a hydroacoustic transducer with a correlation receiver is being evaluated by DALE C. KRAUSE of the Graduate School of Oceanography, UNIVERSITY OF RHODE ISLAND, Kingston, R.I., in association with MARK A. CHRAMIEC, GEORGE M. WALSH and SERGE WISOTSKY of the RAYTHEON COMPANY, Portsmouth R.I., developers of the system. They report that a detailed profile over the continental shelf south of Rhode Island reveals two major unconformities, the Cretaceous-Tertiary (?) and the P1iocene-Pleistocene (?). Bottomset beds of the Pleistocene Block delta; which lies at the edge of the shelf, are clearly seen. Interpretation of the record indicates that a shelf edge now buried at 850 metres below sea level was at sea level at the end of the Cretaceous or during early Tertiary time; that shelf edge was about 15 kilometres seaward of the present one. Furthermore, the top of the continental rise at that time was probably only at 650 metres depth, suggesting the nearby presence of a large river with a large drainage basin, a conclusion similar to that of R.E. GARRISON and R.L. McMASTER who have studies the Pleistocene of the area extensively. 